\title{
MODEL KELEMBAGAAN PERIZINAN BAGI INDUSTRI TEKSTIL DI KABUPATEN BANDUNG
}

\author{
Nur Efendi \\ Jurusan Administrasi Bisnis Fakultas Ilmu Sosial dan Ilmu Politik \\ Universitas Lampung \\ E-mail :nurefendi10@gmail.com
}

\begin{abstract}
ABSTRAK :Perizinan adalah faktor penting yang harus dimiliki oleh sebuah perusahaan tekstil.Perizinan ini bukan hanya penting dalam arti tertib administrasi tetapi juga sebagai legalitas bagi pemerintah untuk melakukan pengendalian atas izin yang telah diberikan.Pada tahun 2012 terdapat 855 perusahaan tekstil di Kabupaten Bandung dan 432 diantaranya adalah perusahaan yang secara formal memiliki izin. Untuk memberikan kepastian kepada calon investor maka pemerintah daerah mengeluarkan beberapa peraturan perizinan sebagai dasar dalam penyelenggaraan perizinan usaha. Tujuan penelitian ini adalah untuk mengetahui model kelembagaan perizinan bagi industri tekstil di Kabupaten Bandung. Metode penelitian yang digunakan adalah metode kualitatif dan pengumpulan data dilakukan dengan teknik wawancara observasi.dan dokumentasi. Hasil penelitian ini menunjukkan bahwa selain aturan formal, terdapat juga aturan informal yang membuat kelembagaan perizinan justru menjadi semakin tidak pasti dalam hal proses, biaya, dan waktu penyelesaian izin. Ketidakpastian ini terjadi karena adanya hambatan-hambatan kelembagaan dan perilaku oportunis dari berbagai pihak yang terlibat pada proses perizinan yang pada akhirnya sangat berpotensi untuk menimbulkan biaya transaksi bagi perusahaan. Kesimpulan yang diperoleh dari penelitian ini adalah bahwa model kelembagaan perizinan yang ada di Kabupaten Bandung belum tertata dengan baik karena masih tingginya ketidakpastian dalam penyelenggaraan perizinan.
\end{abstract}

Kata kunci :Kelembagaan, Ketidakpastian, Hambatan Kelembagaan, Perilaku Oportunis, Biaya transaksi.

\section{INSTITUTIONAL MODEL FOR TEXTILE INDUSTRY LICENSING IN REGENCY BANDUNG}

ABSTRACT :Licensing is an important factor that must be owned by a textile company. Licensing is not only important in the sense of orderly administration but also as to the legality of the government to exercise control over permissions that have been granted. In 2012 there were 855 textile companies in Bandung Regency and 432 of them are companies that have formal permission. To provide certainty to potential investors the government issued several licensing rules as the basis for the implementation of business licensing. The purpose of this study was, first, to determine the institutional licensing models for the textile industry in Bandung Regency. The method used is a qualitative method and data collection was done by using observation interview. The results of this study indicate that in addition to the formal rules, there are also informal rules that make institutional licensingbecame increasingly uncertain in terms of process, cost, and turnaround time permits. This uncertainty is due to the institutional constraints and the opportunistic behavior of the various parties involved in the licensing process, which in turn has the potential to give rise to transaction costs for the company. Conclusion of this study is that the institutional model of licensing in the district of Bandung not well ordered because of the high uncertainty in the in the governance of licensing.

Keywords : Institutional, Uncertainty, Institutional Barriers, Opportunistic Behavior, transaction fee .

\section{PENDAHULUAN}

Keberadaan industri tekstil di Kabupaten Bandung memiliki arti yang penting bukan hanya karena memiliki arti historis, tetapi juga mampu menyerap banyak tenaga kerja.Sebagai salah satu industri manufaktur yang padat karya, industri tekstil memiliki kontribusi yang besar untuk mengurangi angka pengangguran di Jawa Barat pada umumnya yang mencapai 1.982 .448 jiwa pada bulan Mei 2011. ${ }^{1}$

Keberadaan industri tekstil di Kabupaten Bandung bukannya tanpa hambatan.Isu pencemaran lingkungan yang dilakukan oleh industri tekstil merupakan masalah utama yang harus diselesaikan bukan hanya oleh industri tetapi juga oleh pemerintah.Selain itu, terjadinya ekonomi biaya tinggi yang disebabkan oleh tingginya biaya transaksi menjadi masalah lain untuk pengembangan industri ini di masa yang akan datang. Salah satu aspek yang cukup berkontribusi terhadap tingginya biaya transaksi ini adalah ketidakpastian dalam hal perizinan usaha.

Terkait dengan masalah perizinan ini, Badan Penanaman Modal dan Pelayanan Perizinan (BPMPP)
Kabupaten Bandung adalah instansi yang memiliki kewenangan untuk mengeluarkan berbagai perizinan bagi usaha yang investasinya di bawah Rp 10 milyar, baik perizinan baru maupun perpanjangannya. Untuk menjamin kelancaran perizinan ini maka Pemerintah Kabupaten Bandung mengeluarkan Peraturan Daerah (Perda) untuk berbagai objek perizinan usaha yang merupakan aturan main formal dan harus dilaksanakan oleh BPMPP dan semua subjek perizinan. Peraturan Daerah ini diharapkan memberikan kepastian kepada pengusaha tentang proses, biaya, dan waktu penyelesaian perizinan usaha. Namun dalam kenyataannya, banyak sekali keluhan pengusaha terkait dengan perizinan ini, baik menyangkut proses, biaya, maupun waktu penyelesaian, yang dianggap tidak ada kepastian. Berdasarkan uraian di atas maka rumusan masalah dalam penelitian ini adalah "bagaimanakah model kelembagaan perizinan bagi industri tekstil di Kabupaten Bandung. Tujuan penelitian ini adalah mengetahui model kelembagaan industri tekstil di Kabupaten Bandung. 


\section{Tinjauan Pustaka}

Secara konseptual North ${ }^{2}$ mendefinisikan kelembagaan sebagai "the humanly devised constraints that structure political, economic and social interaction." Kendala-kendala yang secara sengaja diciptakan dalam berinteraksi ini meliputi "informal constraints (sanctions, taboos, customs, traditions, and codes of conduct), and formal rules (constitutions, laws, property rights)". Selanjutnya North menjelaskan bahwa "Kelembagaan terdiri dari aturan-aturan formal yang dibuat dalam bentuk undang-undang, common law dan regulasi, dan kendala-kendala informal yang diwujudkan dalam bentuk konvensi, norma-norma berperilaku, serta karakteristik untuk menegakkan keduanya." 3

Sedangkan Ferriero dan Serrano ${ }^{4}$ mendefinisikan kelembagaan sebagai seperangkat aturan formal dan informal serta penegakannya dan secara umum tujuannya adalah untuk memandu perilaku mereka secara individual. Baik North maupun Ferreiro dan Serrano secara jelas mengatakan bahwa dalam kelembagaan terdapat berbagai aturan formal yang harus diiikuti baik secara individu maupun kolektif. Dan pada waktu yang bersamaan, kelembagaan juga membatasi peluang untuk mendapatkan sumbersumber ekonomi yang langka melalui aturan-aturan informal yang sengaja diciptakan untuk itu. Baik aturan formal maupun aturan informal ini pada akhirnya menjadi sebuah institusi sendiri yang disebut sebagai informal institution dan formal institution. ${ }^{5}$

Kelembagaan merupakan panduan bagi setiap individu dalam berinteraksi ketika mereka ingin memenangkan permainan melalui kombinasi keahlian, strategi, dan koordinasi, baik secara adil maupun tidak adil. ${ }^{6}$ Adanya institusi informal yang menjadi constraint bagi setiap individu, menjadikan kelembagaan sebagai collective action in control, liberation and expansion of individual action ${ }^{7}$ Dan ini sekaligus juga menghalangi sifat dasar manusia sebagai makhluk ekonomis yang mempunyai kecenderungan untuk bertindak rasional dalam memenuhi kebutuhannya. Peluang dan hambatan yang terdapat di dalam suatu masyarakat mengharuskan individu untuk berinteraksi satu sama lainnya agar memperoleh hasil yang optimal. Hambatan bagi seseorang menjadi peluang bagi yang lainnya ${ }^{8}$

Kelembagaan berbeda dengan organisasi. ${ }^{9}$ Kelembagaan adalah rules of the game yang sengaja dibuat manusia dalam berinteraksi. ${ }^{10}$ Kelembagaan adalah seperangkat aturan yang menata perilaku hubungan antara individu atau kelompok. ${ }^{11}$ Sedangkan organisasi adalah the players, kelompok individu yang terikat oleh tujuan yang sama untuk mencapai tujuan. ${ }^{12}$ Lebih jelas lagi Avellaneda ${ }^{13}$ mengutip dari North (1993) yang

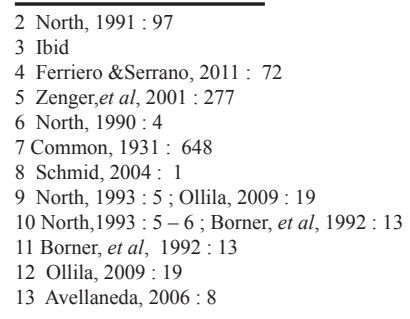

membedakan the rules of the game (institutions), the players of the game (individuals and organisations) dan the way the game is played. Dalam konteks ini, perusahaan yang diwakili oleh manajemen adalah the player, demikian juga halnya dengan perusahaan mitra, pesaing, birokrasi, asosiasi, dan semua pihak yang terlibat dalam proses pertukaran adalah the player. Merekalah yang menciptakan dan memainkan aturan yang ada baik formal maupun informal. Dan yang lebih penting lagi adalah the way the game is played.

Secara umum tujuan kelembagaan adalah untuk memandu perilaku individu. ${ }^{14}$ Rasionalitas yang dimiliki individu bukan tidak terbatas. Ada banyak informasi yang tidak dketahui oleh individu yang mengharuskannya berinteraksi dengan individu ataupun kelompok lain. Interaksi ini akan menghasilkan sesuatu yang optimal jika mengikuti aturan main yang ada. Namun demikian, selalu ada keinginan salah satu pihak untuk mengambil keuntungan yang lebih besar. Karena itulah harus ada kelembagaan yang mengatur interaksi ini.

Kelembagaan tidak selalu dan bahkan diciptakan tidak untuk menjadi efisien. ${ }^{15}$ Tetapi setidaknya aturan formal diciptakan untuk melayani kepentingan mereka dengan bargaining power untuk menciptakan aturan yang baru. Ada faktor uncertainty yang harus dihadapi berkaitan dengan incomplete information dan bounded rationality dalam pertukaran yang dilakukan manusia. Kelembagaan diciptakan untuk menurunkan ketidakpastian ini. ${ }^{16}$ Oleh sebab itu ada biaya transaksiyang harus ditanggung oleh masingmasing pihak yang melakukan pertukaran.Biaya transaksi terjadi karena (1) kondisi ketidak pastian (uncertainty), (2) suatu kegiatan sering terjadi (frequency), (3) dansuatu kegiatan transaksi atas barang/ jasa yang bersifat khusus (specificit). ${ }^{17}$ Kondisi ini diperkuat dengan asumsi bahwa agent memilikibounded rationality dan setidaknya beberapa diantaranya ada kecenderungan untuk opportunistic behavior. ${ }^{18}$ Perilaku agent ini sangat berpotensi untuk meningkatkan biaya transaksi melalui biaya keagenan.Biaya agensi timbul dalam situasi apa pun yang melibatkan usaha kerjasama oleh dua orang atau lebih meskipun tidak ada hubungan principal-agentyang jelas. ${ }^{19}$ Dan dalam hal ini, agent diperankan oleh aparat birokrasi yang terkait dengan perizinan.

Tata kelola kelembagaan tidak selamanya berjalan dengan mulus sehingga bisa menurunkan ketidakpastian ${ }^{20}$ dan menciptakan pertumbuhan. ${ }^{21}$ Ada banyak aspek yang menghambat pencapaian tujuan dari suatu kelembagaan, yaitu apa yang disebut dengan institutional barriers $^{22}$ Rintangan kelembagaan adalah hambatan dalam lingkungan kelembagaan yang mencegah mekanisme seleksi pasar berfungsi dengan baik. ${ }^{23}$

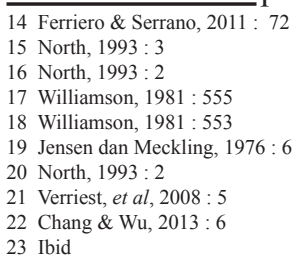




\section{Proposisi}

Model kelembagaan perizinan bagi industri tekstil di Kabupaten Bandung terkait dengan perilaku aparat dan hambatan kelembagaan.

\section{METODE}

Tipe penelitian ini adalah deskriptif eksploratif yang ditujukan untuk memperoleh gambaran yang jelas dan mendalam tentang model kelembagaan perizinan di Kabupaten Bandung. Untuk bisa mendeskripsikandan menjelaskan model kelembagaan perizinan ini maka digunakan pendekatan induktif dengan metode kualitatif. Objek penelitian ini adalah kelembagaan perizinan bagi industri tekstil di Kabupaten Bandung, yang berfokus pada pelaksanaan aturan perizinan yang meliputi proses, biaya, dan waktu penyelesaianperizinan. Teknik pengumpulan data yang digunakan adalah wawancara, observasi dan dokumentasi. Informan dalam penelitian ini adalah dari pihak perusahaan yaitu pemilik PT. SSC, pemiliki CV. SMLdan manajer HRD PT. GPS, Kepala Bidang Perizinan dan seorang staf, dan 3 (tiga) orang masyarakat pengguna layanan perizinan. Validasi data dilakukan dengan dilakukan dengan metode triangulasi sumber.

\section{HASIL DAN PEMBAHASAN}

Penyelenggaraan perizinan di Kabupaten Bandung didasarkan pada Perda Nomor 21 Tahun 2007 Tentang Pembentukan Lembaga Teknis Daerah Kabupaten Bandung.Pada pasal 2 Perda ini dinyatakan bahwa salah satu lembaga teknis yang dibentuk adalah Badan Penanaman Modal dan Pelayanan Perizinan (BPMPP).Berdasarkan Perda Nomor 21 Tahun 2007 ini ditetapkanlah Peraturan Bupati Kabupaten Bandung Nomor 13 Tahun 2008 Tentang Penyelenggaraan Pelayanan Perizinan Terpadu di Kabupaten Bandung. Pada pasal 3 Peraturan Bupati ini ditegaskan bahwa ada 11 (sebelas) pelayanan perizinan dan 4 (empat) pelayanan non perizinan yang dilayani oleh BPMP Kabupaten Bandung. Dalam konteks ini, perizinan dan non izin yang terkait dengan industri tekstil adalah (1) Surat Persetujuan Penanaman Modal ; (2) Persetujuan Prinsip ; (3) Izin Lokasi; (4) Izin Pemanfaatan Tanah (IPT) ; (5) Izin Mendirikan Bangunan (IMB); (6) Izin Undang-Undang Gangguan atau Hinder Ordonantie (HO); dan (7) Izin Usaha Industri (IUI).

Kelembagaan perizinan usaha di Kabupaten Bandung ditandai oleh proses yang berbelit-belit. Menurut pengusaha yang menjadi informan dalam penelitian ini, proses perizinan kita "ribet" dan tidak jelas.Proses ini tidak akan pernah diketahui dimana ujungnya jika mereka belum mengeluarkan sejumlah uang.Uang ini bukan ditujukan untuk menyederhanakan dan mempercepat, tetapi hanya untuk melancarkan proses. Artinya, berapapun uang yang dikucurkan tidak menjamin bahwa proses tersebut akan menjadi jelas dan cepat. Meskipun sudah ada SOP nya tetapi dalam pelaksanaannya kan tidak selalu begitu. Yang terjadi selanjutnya adalah aparat merangkap sebagai "calo". ${ }^{24}$ Calo ini bukan hanya 24 Wawancara dengan pemilik PT SSC tanggal 2 September 2013 dari dalam tetapi juga dari luar instansi pemerintah. Hal ini semakin memperkuatkesan adanya suatu proses panjang yang berbelit-belit apabila berurusan dengan aparatur pemerintah. ${ }^{25}$ Adanya keengganan pengusaha untuk mengurus sendiri keperluan perizinan usahanya menunjukkan bahwa ada sesuatu yang salah dengan birokrasi pemerintahan.Praktek suap dan percaloan yang justru dilakukan sendiri oleh oknum aparat semakin menunjukkan bahwa praktek birokrasi kita masih jauh dari ethics public office yang ideal. ${ }^{26}$

Kembali pada proses perizinan, sebenarnya ada banyak perizinan dan non perizinan yang harus dimiliki oleh sebuah perusahaan tekstil untuk bisa beroperasi. Salah satu pengusaha bahkan menyebutkan ada 31 izin.Dalam prakteknya, pelaksanaan perizinan ini saling tumpang tindih dan diatur dalam Peraturan Daerah yang berbeda. Permasalahan terkait banyaknya izin ini selain dikarenakan banyaknya objek perizinan, juga dikarenakan oleh keinginan pihak Pemerintah Daerah untuk mengejar target PAD dari sektor pajak dan retribusi. Akibatnya adalah munculnya objekobjek retribusi yang dikaitkan dengan perizinan.Hal ini pada akhirnya bermuara pada kewajiban pengusaha untuk membayar retribusi yang terkadang sangat tidak "fair".Hampir setiap perda yang dikeluarkan Pemerintah Daerah berujung pada retribusi dan ini dikaitkan dengan izin dan perpanjangan izin atau dengan fasilitas yang dimiliki perusahaan seperti alat pemadam kebakaran, alat penangkal petir, dan lain-lainnya.Ini adalah salah satu contoh dari aturan pemerintah yang "hanya kejar target" sehingga apapun fasilitas yang ada di perusahaan dijadikan objek retribusi dan dibuatkan perdanya.

Pada tahun 1997, dalam artikelnya Brunetti, et al ${ }^{27}$ menyebutkan bahwa hambatan kelembagaan pertama dalam melakukan bisnis adalah aturan-aturan untuk memulai usaha. Dan pada tahun 2008, Luo \&Junkunc ${ }^{28}$ menyatakan bahwadua rintangan administratif yang teratas dalam kelembagaan adalah persyaratan dokumentasi yang berlebihan dan informasi tentang aturan dan regulasi yang tidak memadai. Jika diteliti lebih lanjut, panjangnya proses perizinan yang harus dilalui oleh perusahaan bukan hanya karena sangat banyaknya objek perizinan tetapi juga karena rekomendasi dan persyaratan teknis sehingga kesan bahwa perizinan itu panjang dan berbelit-belit sangat terlihat dengan jelas. Meskipun kebijakan pelayanan Perizinan Terpadu Satu Pintu telah mulai dilaksanakan namun kebijakan satu pintu yang dimaksud masih dalam hal koordinasi.Hal ini disebabkan karena "satu pintu" yang dimaksud masih terbatas pada instansi yang mengeluarkan izin yaitu BPMPP Kota/Kabupaten atau Propinsi.Sedangkan yang terkait dengan masalah rekomendasi teknis tetap berada di instansi teknis. Kondisi sulitnya untuk mendapatkan pelayanan yang berkualitas seperti yang terjadi dalam proses perizinan ini, menurut Silalahi (1997) ${ }^{29}$ akan mengakibatkan munculnya take and give antara pemohon izin dengan

25 Kristiadi,1994: 93

26 Barry, $2007: 2$

27 Brunetti, et al $1997: 20$

28 Luo \&Junkunc, $2008: 134$

29 Waluyo, $2007: 133$ 
aparat dan akan memunculkan suap. ${ }^{30}$

Berdasarkan hasil penelitian ini, persyaratan perizinan bisa dibagi menjadi 2 (dua) kelompok, yaitu persyaratan umum dan persyaratan khusus. Beberapa peryaratan umum itu adalah (1) Fotocopy KTP Pemohon, (2) Fotocopy akta pendirian perusahaan, (3) Fotocopy tanda pelunasan PBB terakhir, dan (4) Fotocopy NPWP. Sedangkan persyaratan khusus yang harus dipenuhi diantaranya adalah (1) Peta lokasi, (2) Site Plan, (3) Surat keterangan Kades/Lurah diketahui/disetujui Camat bahwa lokasi/tanah tidak dalam sengketa dan siap digunakan, (4) Proposal/ rencana proyek secara garis besar, (5) Fotocopy surat persetujuan Kepala BKPM, (6) Surat keterangan sanggup memberikan ganti rugi kepada pemilik lahan, (7) Surat keterangan tidak berkeberatan dari warga, (8) Gambar konstruksi, (9) Fotocopy rencana bangunan dan prasarana kawasan industri yang disetujui pemerintah kabupaten/kota, (10) Fotocopy UKL UPL atau AMDAL, dan (11) Rekomendasi dari tim teknis.

Kesulitan pengusaha dalam proses perizinan adalah dalam memenuhi persyaratan khusus. Kesulitan ini bukan hanya karena prosesnya yang cukup panjang tetapi juga adanya sejumlah dana yang harus dikeluarkan untuk melancarkan prosesnya tadi. Dalam hal ini, uang adalah faktor penting disamping adanya akses ke pejabat tertentu. Sehingga kekuatan uang dalam hal ini hanya berfungsi untuk mengurangi ketidakpastian bahwa proses perizinan itu memang berjalan. Dan tidak ada jaminan dari pihak "provider" bahwa proses tersebut akan selesai dalam waktu yang telah dijanjikan.

Dalam konteks hubungan principal-agent yang terjadi antara aparat birokrasi dengan pengusaha,terdapat kesan bahwa aparat lebih menunjukkan perilaku sebagai agent. Dalam perjalanannya, fungsi agent yang dijalankan oleh aparat birokrasi telah mengubahnya menjadi sosok yang opportunistic.Keterbatasan informasi yang dimiliki pengusaha dan kurangnya sosialisasi aturan, menyebabkan hubungan antara pengusaha sebagai prinsipal dan aparat perizinan sebagai agent menjadi timpang dan tidak saling menguntungkan.Hal ini terjadi karena kedua belah pihak memiliki orientasi yang berbeda. Disatu pihak, pengusaha menginginkan agar proses perizinannya berjalan dengan lancar dan cepat. Namun dipihak lain, oknum petugas melihat pengusaha sebagai ladang yang siap untuk dipanen. Semakin tertunda penyelesaian perizinannya,semakin lama juga mereka bisa berhubungan dan itu berarti bahwa semakin banyak juga dana yang bisa "dipanen" dari pengusaha. Untuk memenuhi orientasi ini maka berbagai kendala administratif disiapkan secara cermat, mulai dari peryaratan yang masih kurang lengkap, petugas yang mengurus sedang verifikasi lapangan, belum diparaf atau pejabat yang tidak masuk kantor.

Sikap aparat yang seperti ini merupakan bukti bahwa tingkat kepedulian aparat birokrasi terhadap kebutuhan masyarakat masih rendah. ${ }^{31}$ Sikap peduli

\section{$30 \mathrm{Ibid}$}

31 Siagian, $1994: 102$ yang seharusnya dimiliki aparat birokrasi, oleh sebagian oknum dilekatkan pada orientasi nilai-nilai ekonomi sehingga aliran informasi hanya terjadi pada kalangan internal dan pihak luar yang sudah memiliki akses ke dalam.Kondisi yang serba tidak pasti inilah yang menyebabkan banyak pengusaha yang mewakilkan pengurusan perizinannya kepada pihak ketiga yang bertindak sebagai "calo".Dalam prakteknya, faktor "kedekatan" dan kemudahan akses yang dimiliki calo menjadi penentu untuk lancarnya proses penyelesaian perizinan yang dimohonkan oleh pengusaha. Untuk menjaga "kedekatan dan kemudahan akses" itu, calo harus "murah hati" dan dermawan kepada setiap staf yang ada di bagian perizinan dan dinas teknis terkait. Meskipun untuk itu ia harus mengeluarkan dana awal, namun untuk kepentingan jangka panjang pendekatan seperti ini sangat diperlukan. Berbagai upaya dilakukan dalam rangka menjalin dan memperkuat hubungan dimasa depan dengan staf dan pejabat daerah, mulai dari ajakan makan siang sampai memenuhi permintaan "khusus". ${ }^{32}$ Oleh sebab itu tidaklah mengherankan jika seorang calo bisa mempunyai hubungan dengan kepala seksi, kepala bidang, kepala bagian di Badan Penanaman Modal Perizinan, dan beberapa kepala dinas teknis bahkan sampai ke Bupati dan anggota dewan. Intinya adalah bahwa komunikasi harus dibuka dengan pejabat yang memiliki akses kunci sehingga bisa memberi bantuan pada saat dibutuhkan. ${ }^{33}$

Proses perizinan yang cukup panjang dan berbelit-belit ini juga menjadi alasan lain bagi beberapa pengusaha tekstil untuk tidak mengurus perizinan usahanya. Banyaknya izin yang harus dipenuhi membuat pengusaha tekstil mempunyai pandangan negatif terhadap proses perizinan ini. Ada banyak izin namun tidak semuanya berkaitan langsung usaha yang mereka lakukan.Sebagian besar izin yang diberikan hanya formalitas dan sangat jauh dari tujuan pengendalian. ${ }^{34}$ Masalah yang dihadapi oleh pengusaha bukan hanya proses izin yang lama dan mahal tetapi juga adanya rekomendasi teknis yang harus mereka urus secara terpisah dari perizinan. Terkait dengan rekomendasi teknis ini, ada banyak instansi teknis yang terlibat dalam pengurusan perizinan. Berdasarkan Keputusan Bupati Bandung Nomor 503 Tahun 2008 ada 15 (lima belas) Satuan Kerja Pemerintah Daerah (SKPD) yang dilibatkan sebagai anggota tim teknis perizinan dan non perizinan. Sedangkan dalam konteks perizinan bagi industri tekstil, dikenal yang namanya Tim Sembilan. ${ }^{35}$, yaitu :

\footnotetext{
32 Sumber : Wawancara dengan seorang calo perizinan tanggal 16 Juli 2013.

33 Sumber : Wawancara dengan seorang calo tanggal 16 Juli 2013. 33 Sumber: Wawancara dengan seorang calo tanggal 16 Juli 2013.
34 Sumber : Wawancara dengan Manajer SDM PT. GPS tanggal 28 Agustus 2013. Beliau
mengatakan bahwa : "Ada ijin penangkal petir. Itu kewenangannya sebenarnya ke malaikat". Sebenarnya itu tidak nyambung-ngambung amatlah.Ini di ada-adain.Ini biayanya segini.Cobalah disederhanakan.Kenapa harus mengada-ada.Kalau bejana tekan, boiler, limbah, itu ada relevansinya, walaupun untuk efektifitasnya harus ada pemantauan yang baguslah sehingga perizinannya bukan hanya bersifat formalitas saja.Dan memang, pemerintah kabupaten dan cenderungnya formalitas.Jadi setelah izin itu diterbitkan tidek dilanjutken dengan pengawasan yang seharusya Jadi tinggal izin itu diterbitkan tidak dilanjutkan dengan pengawasan yang seharusnya.Jadi tinggal tunggu lagi taho mendang Sehingga akhirnya, rambu-rambu yang sench la dibcikn Jadi yang dikejar sebenarnya uangnya saja.Lagipula kita tidak tahu berapa tarif yang sebenarnya."

35 Sumber : Wawancara dengan Pemilik PT SSC tanggal 2 September 2013
} 
Kepala Bappeda.

Kepala BPLH.

Kepala Dinas Perhubungan.

Kepala Dinas Perumahan, Penataan Ruang,

dan Kebersihan (Dispertasi).

Kepala Dinas Koperasi, UKM, Perindustrian, dan Perdagangan.

Kepala Dinas Bina Marga.

Kepala Dinas Sumber Daya Air, Pertambangan

dan Energi.

Kepala Satuan Polisi Pamong Praja.

Kepala Kantor Pertanahan.

Permasalahan dalam proses mendapatkan rekomendasi teknis ini adalah tidak adanya kepastian tentang kapan rapat teknis bisa dilakukan, dan besarnya biaya yang harus ditanggung oleh pemohon. Meskipun dalam Keputusan Bupati Nomor 503 tahun 2008 tersebut dikatakan bahwa biaya pelaksanaan tugas tim dibebankan kepada APBD, namun dalam kenyataannya pemohon masih harus "menjamu" dan memberikan uang transport kepada anggota tim yang melakukan verifikasi dan pada saat rapat pembahasan.

Dari uraian-uraian yang telah diberikan di atas terlihat jelas bahwa proses perizinan untuk industri tekstil dirasakan sangat berbelit-belit dan menyulitkan bagi pengusaha. Faktor ketidakpastian tentang proses yang harus ditempuh membuat pengusaha menggunakan jasacalo sebagai pihak ketiga, baik calo yang internal maupun eksternal. Keberadaan calo yang berperilaku seperti agent ${ }^{36}$ ini disatu sisi sangat membantu sehingga pengusaha tidak perlu menghabiskan waktu dan energi untuk mengurus proses perizinan yang memang dibuat menjadi tidak jelas. Namun disisi lain, pengusaha juga harus mengeluarkan sejumlah uang yang dapat dikategorikan sebagai biaya transaksi ${ }^{37}$ dalam proses perizinan.

\section{Biaya Perizinan}

Biaya perizinan merupakan salah satu aspek yang memiliki ketidakpastian yang tinggi dalam pengurusan perizinan.Ketidakpastian ini terjadi karena tidak tersosialisasinya perda-perda yang terkait dengan retribusi perizinan, sehingga banyak pengusaha yang tidak mengetahui tarif retribusi. Selain itu, Ketidaktahuan ini juga disebabkan karena ketidakpedulian pengusaha dengan perda-perda yang dikeluarkan pemerintah daerah. Hal ini dikarenakan "ada banyak Perda yang pada akhirnya berujung pada duit." ${ }^{38}$ Sehingga setiap perda yang dikeluarkan pemerintah daerah yang terkait dengan industri dikonotasikan dengan retribusi. Pemerintah daerah dalam rangka memenuhi target APBD seringkali memanfaatkan industri sebagai objek retribusi.Apakah uangnya masuk ke APBD?Tidak. Industri tetap keluar duit, yang untung bapak-bapak itu." ${ }^{39}$

Apakah kondisinya memang sudah demikian parah

\footnotetext{
36 Williamson, 1981: 555. Williamson mengatakan bahwa setidaknya sebagian agent berprilaku opportunistic.

37 Furubotn dan Richter,2005: 40

38 Sumber : Wawancara dengan Manajer SDM PT GPS tanggal 28 Agustus 2013. 39 Ibid
}

sepertiitu?Dari wawancara dengan beberapa pengusaha diperoleh informasi bahwa sangat sulit bagi mereka untuk mengetahui tarif retribusi yang sesungguhnya. Akibatnya pengusaha harus mengeluarkan sejumlah dana yang jumlahnya tidak pasti dan berbeda-beda di antara pengusaha. Seperti dikatakan oleh pemilik CV SML, untuk memperpanjang izin usaha industri dia dikenakan biaya sebesar Rp 3,5 juta. Alasannya adalah karena IUI harus dilengkapi lagi dengan kajian lingkungan dan biaya untuk kajian lingkungan tersebut adalah Rp 2,5 juta. Artinya, herregistrasi IUI yang harus dibayar adalah Rp 1 juta. Padahal jika mengacu pada Peraturan Bupati Bandung Nomor 13 Tahun 2008, biaya herregistrasi IUI untuk perusahaan sekelas CV. SML yang termasuk kategori industri menengah, biaya herregistrasi IUI tidak lebih dari Rp 250.000,00. Artinya, jika yang disetorkan ke kas daerah adalah $\mathrm{Rp} 250.000,00$ maka kelebihannya akan masuk ke kantong pribadi oknum. Oleh karena itu tidak mengherankan jika dalam penetapan biaya perizinan ini terjadi tawar menawar antara pengusaha dengan petugas. ${ }^{40}$

Dari hasil penelusuran terhadap peraturan tentang retribusi daerah ${ }^{41}$, serta wawancara dengan Kabid Perizinan BPMPP Kabupaten Bandung diketahui bahwa perizinan yang ada retribusi khususnya yang terkait dengan industri tekstil adalah IMB dan HO. ${ }^{42}$ Meskipun demikian, dalam prakteknya hampir semua perizinan yang diberikan oleh BPMPP Kabupaten Bandung mengharuskan pemohon untuk mengeluarkan sejumlah uang, baik untuk retribusi yang ada landasan hukumnya maupun uang yang dibayarkan hanya sebagai pungutan oleh oknum petugas. ${ }^{43}$ Dan dalam proses penetapannyapun bisa ditawar tergantung pada kedekatan antara pemohon atau calo dengan oknum petugas. ${ }^{44}$ Praktek pungutan yang seperti ini pada akhirnya menjadi sebuah kebiasaan dalam hubungan antara pengusaha dengan petugas di BPMPP.

Praktek pungutan yang tidak resmi dalam kaitannya dengan perizinan ternyata tidak terbatas hanya di kantor BPMPP, tetapi juga terjadi di kantor Dinas Teknis yang terkait, kecamatan, Desa, dan bahkan sampai ke tingkat RT. Pungutan ini diadakan terkait dengan adanya rekomendasi atau surat keterangan yang harus diberikan oleh RT, Kepala Desa, dan Camat sehubungan dengan permohonan izin yang diajukan. Rekomendasi yang diberikan oleh dinas teknis tidak mungkin gratis. Meskipun besarnya dana untuk rekomendasi teknis ini relatif, namun tetap saja menjadi high cost bagi perusahaan. Oleh sebab itu, sangat beralasan jika pengusaha mengatakan bahwa pengurusan perizinan, mulai dari tingkat yang paling bawah sampai ke bupati sangat sarat dengan uang. Meskipun besarnya dana yang dikeluarkan tidak selalu sama, namun dapat dipastikan

40 Ibid

41 Lihat UU Nomor 28 Tahun 2009, Perda Nomor 13 Tahun 2012 Tentang Perizinan Tertentu di Kabupaten Bandung.

42 Sumber: Wawancara dengan Kabid Perizinan BPMP Kabupaten Bandung

43 Sumber: Wawancara dengan Pemilik CV SML dan Manajer PT GPS tanggal 28 Agustus 2013

44 Sumber: Wawancara dengan calo perizinan tanggal 16 Juli 2013. 
bahwa semakin tinggi jabatannya, semakin besar juga dana yang harus disetorkan. Dana didistribusikan secara berjenjang dari staf sampai ke Kepala Badan. ${ }^{45}$ Bahkan menurut salah satu pengusaha, untuk tingkat desa saja bisa mencapai Rp 7,5 juta. ${ }^{46}$

Praktek pungutan atas biaya perizinan ternyata tidak terbatas pada retribusi dan "biaya cetak atau biaya operasional" semata, tetapi juga pungutan terhadap objek yang sudah tidak dikenakan retribusinya. Seperti diakui oleh salah satu pengguna layanan perizinan, ${ }^{47}$ meskipun ia sudah mengetahui bahwa izin lokasi itu tidak ada retribusinya, namun tetap saja perusahaan tempat ia bekerja harus membayarnya. Dan bahkan, karena izin lokasi tersebut ditandatangani oleh Bupati maka perusahaan juga harus mengeluarkan dana untuk Bupati. ${ }^{48}$ Sedangkan untuk bisa sampai ke Bupati, berkas izin tersebut harus melalui beberapa tahapan dan setiap tahapnya membutuhkan paraf yang tidak mungkin "kosong".

Munculnya berbagai komponen biaya terkait dengan perizinan ini adalah dampak dari pelaksanaan aturan formal yang mengharuskan pengusaha untuk melakukan "roadshow" guna melengkapi persyaratan perizinan. Akan tetapi seperti dikatakan oleh North, kelembagaan tidak selalu dan bahkan diciptakan tidak untuk menjadi efisien. ${ }^{49}$ Ada masalah incomplete information dan bounded rationality yang menyebabkan terjadinya ketidak pastian dalam bertransaksi. Oleh sebab itu, munculnya berbagai komponen biaya sebagai akibat dari kondisi ini adalah konsekuensi logis dari keterbatasan rasional dan informasi yang tidak lengkap tadi.Biaya transaksi yang muncul dalam kondisi ini adalah risiko yang harus ditanggung atas pilihan yang dibuat oleh pengusaha. Kelembagaan tidak bisa berjalan sendiri tanpa ada aktor di dalamnya. dan aktor ini mempunyai kepentingan yang sifatnya interdependence. ${ }^{50}$ Pengusaha sebagai aktor dalam kelembagaan perizinan ini sangat terikat dengan aktor lain, yaitu aparat birokrasi. Bagaimana aturan perizinan itu kemudian dimainkan sangat tergantung pada perilaku pengusaha dan aparat.Dalam hal ini, perilaku oportunis bisa saja muncul dari kedua belah pihak, tergantung dari besarnya keuntungan yang bisa mereka peroleh dari hubungan ini. Sehingga yang terjadi disini adalah apa yang disebut Ollila sebagai bargaining transaction, ${ }^{51}$ dimana harga sangat menentukan dalam proses bargaining.

\section{Lamanya Waktu Pengurusan Perizinan}

Lamanya waktu pengurusan perizinan sangat terkait dengan proses perizinan yang dianggap berbelit-belit dan besarnya biaya yang dikeluarkan oleh pengusaha. Meskipun dalam SOP tentang proses perizinan sudah dikatakan bahwa waktu penyelesaian $45 \mathrm{Ibid}$

46 Sumber : Wawancara dengan Pemilik PT SSC tanggal 2 September 2013. Dijelaskan bahwa investor yang mau investasi, di desa saja sudah dipungut uang Rp 2 juta sampa Rp 7,5 juta. Itu baru di desa, untuk izin domisili, surat keterangan domisili. "Itu bisa mencapai Rp 7,5 juta. Kalau keterangan domisili saja kayak begitu, bagaimana kalau izin lokasi?"

47 Sumber : Wawancara dengan pengguna layanan perizinan di Kabupaten Bandung.

48 Ibid

49 North, $1993: 3$

50 Ollila, $2009: 12$

51 Ibid perizinan paling lama adalah 14 hari kerja namun tetap saja dalam prakteknya hal itu jarang terjadi. Berbagai kendala bisa muncul pada saat proses, seperti persyaratan yang kurang lengkap, petugas yang mengerjakan sedang keluar kantor, pejabat yang sedang tidak ditempat, atau kendala-kendala lainnya yang semuannya bermuara pada seberapa besar biaya yang telah dinegosiasikan dan proses pencairannya. ${ }^{52}$ dan kalaupun waktu penyelesaian semua perizinan tersebut sesuai dengan SOP, maka untuk bisa memulai usaha, setidaknya dibutuhkan waktu selama 82 hari untuk pngurusan perizinan. ${ }^{53}$

Dalam prakteknya sangat banyak permohonan izin yang tidak selesai sesuai dengan batas waktu yang dijanjikan. Dan jika sudah demikian maka yang terjadi selanjutnya adalah, "kami akan "membantu prosesnya di dalam."Artinya, praktek pengurusan perizinan yang begitu lama, disadari atau tidak, membuka peluang bagi terjadinya percaloan, terutama yang dilakukan oleh oknum petugas itu sendiri.Jika diperhatikan aturan tentang perizinan di Kabupaten Bandung, banyak sekali persyaratan administrasi dan teknis yang harus dilengkapi terlebih dahulu sebelum permohonan izin diproses lebih lanjut. Upaya untuk memenuhi persyaratan inilah yang seringkali dikeluhkan dan menghambat proses perizinan. Dalam hal ini, kedekatan personal tidak akan bisa mempercepat proses. Harus ada satu variabel lain yang dapat menunjang percepatan proses penyelesaian, yaitu biaya pergaulan. Seperti dikatakan oleh seorang pengusaha,"kalau normatif pasti lama.Tapi kalau ada biaya pergaulannya, prosesnya bisa agak dipercepat, tergantung biaya pergaulannya besar atau tidak." 54

Lama dan besarnya biaya pengurusan perizinan bagi industri tekstil juga tidak bisa dilepaskan dari kendala sosial kemasyarakatan. Kendala ini bukan hanya dalam hal besarnya biaya yang harus dikeluarkan dan lamanya waktu untuk bernegosiasi, tetapi juga adanya aturan main yang "dipaksakan" dimana perusahaan harus menerima beberapa persyaratan yang diajukan oleh masyarakat. Beberapa persyaratan itu diantaranya adalah "karyawannya mesti dari warga sekitar", perbaikan sarana dan prasarana umum yang ada di sekitar pabrik, dan keharusan untuk memberikan kompensasi untuk warga yang tinggal di zona pabrik, yang batasan jaraknya juga tidak jelas. ${ }^{55}$. Dalam konteks perizinan ini, setidaknya ada beberapa izin yang mensyaratkan persetujuan tetangga, yaitu izin lokasi, IPT, IMB, dan HO. Ini berarti bahwa untuk beberapa izin ini perusahaan harus mengeluarkan sejumlah dana dan melakukan negosiasi dengan warga yang terkena dampak langsung dan tidak langsung dari operasi perusahaan. Dan ini belum termasuk izin untuk pengelolaan limbah industri karena seperti diketahui, industri tekstil termasuk industri polutan. ${ }^{56}$

\footnotetext{
52 Sumber : Wawancara dengan pengguna layanan perizinan tanggal 15 Juli 2013, Beliau mengatakan bahwa : “...saya kemarin janjinya kan Rp 7,5 juta. Baru dikasih 4 juta. Sampai sekarang tidak beres-beres. Padahal janjinya 2 hari. Alasannya, orangnya tidak ada, keluar, meeting, besok ada.Seminggu masih belum Alasannya, orangnya tidak ada, keluar, meeting, besok ada.Seming
ada hasilnya.Besok saja.Besok saya tunggu masih belum juga." ada hasilnya.Besok saja.Besok saya tunggu masih belum juga."

53 Lihat Lampiran III Peraturan Bupati Nomor 13 Tahun 2008
54 Sumber : Wawancara dengan pemilik PT SSC tanggal 2 September 2013 55 Sumber: Wawancara dengan pemilik CV SML tanggal 28 Agustus 2013 56 Sumber : Wawancara dengan Sekretaris BPLH Kabupaten Bandung tanggal 18 Juli 2013
} 
Dari hasil penelitian ini dapat diidentifikasi beberapa aturan informal yang muncul sebagai akibat dari pelaksanaan aturan formal. Aturan informal yang berlaku dalam kelembagaan perizinan di Kabupaten Bandung ini adalah :

Kebiasaan untuk membayarkan sejumlah uang dalam kaitannya dengan rekomendasi teknis yang disyaratkan dalam aturan formal.

Kebiasaan untuk menggunakan jasa staf dinas teknis untuk memenuhi persyaratan teknis yang harus dilengkapi oleh perusahaan.

Keharusan untuk "menjamu" pegawai dan pejabat yang melakukan visitasi ke lokasi perusahaan

Kebiasaan menggunakan jasa calo dalam pengurusan perizinan

Kebiasaan untuk mengeluarkan biaya untuk semua urusan yang terkait dengan perizinan.

Kebiasaan untuk menggunakan "orang dalam" Keharusan perusahaan untuk membayar kompensasi kepadamasyarakat.

Keharusan perusahaan untuk menerima masyarakat sekitar untuk bekerja di pabrik.

\section{Potensi Pungutan Yang Terkait Dengan Perizinan}

Berbagai pungutan di luar retribusi yang muncul dalam pengurusan perizinan ternyata tidak terlepas dari persyaratan perizinan yang diatur dalam Peraturan Bupati Kabupaten Bandung.Banyaknya persyaratan teknis yang harus dipenuhi membuka peluang bagi oknum aparat di berbagai dinas teknis terkait untuk memanfaatkan kondisi ini dengan melakukan berbagai pungutan kepada pengusaha. Ollila ${ }^{57}$ mengatakan bahwa kelembagaan adalah seperangkat aturan, "rules of game of right." Namun dalam pelaksanaannya, seperti juga dikatakan oleh Ollila,is much more difficult. Oleh sebab itu, selalu terjadi plasticity dalam pelaksanaan aturan main terutama dalam kaitannya dengan pihak eksternal.Untuk bisa mendapatkan kelenturan dalam pelaksanaan aturan itu maka harus diciptakanIncentive Compatible ${ }^{58}$ dalam hubungan antara pengusaha dengan aparat birokrasi.Dalam hal ini,agent yang diperankan oleh aparat is better informed ${ }^{59}$ yang dapat saja berbuat curang ${ }^{60}$ karena berpikiran bahwa "he should be compensated by a much higher income. " ${ }^{61}$ Kecenderungan aparat untuk berperilaku opotunis ini akan menimbulkan biaya keagenan bagi principal yang dalam hal ini adalah pengusaha.

Dalam hal perizinan usaha bagi industri tekstil di Kabupaten Bandung, setidaknya ada 14 titik dimana pungutan tersebut sangat mungkin terjadi, seperti yang terlihat pada gambar 1(lihat lampiran 1)

\section{Hambatan Kelembagaan Dalam Perizinan}

Kelembagaan adalah seperangkat aturan formal dan informal ${ }^{62}$ yang bertujuan untuk menurunkan ketidakpastian dalam pertukaran. ${ }^{63}$ Ketidakpastian ini

\section{Olilla, 2009: 19}

58 Bos, Dieder, $2001: 11$

59 Ibid

60 Bos, Dieder, $2001: 10$

61 Bos, Dieder, $2001: 11$

62 North, $1993: 5$; Ferriero \& Serrano, $2011: 72$

63 North, $1993: 2$ bisa dikurangi karena kelembagan memberikan "the humanly devised constraints" 64 dalam bentuk the rules of the game ${ }^{65}$ yang mengatur perilaku interaksi individu atau kelompok. ${ }^{66}$ dalam prakteknya, keberadaan aturan formal dan informal ini tidak selamanya mampu menurunkan ketidak pastian dalam pertukaran. Ada banyak aspek yang menghambat pencapaian tujuan kelembagaan yaitu apa yang disebut Chang dan $\mathrm{Wu}$ sebagai institutional barriers ${ }^{67}$

Dalam konteks penelitian ini, ditemukan ada beberapa hambatan kelembagaan dalam pengurusan perizinan bagi industri tekstil di Kabupaten Bandung, yaitu :

Banyaknya aturan formal dan informal yang harus dipenuhi dan berimplikasi pada biaya bagi perusahaan.

Banyaknya aturan perizinan yang harus dipenuhi dengan berbagai persyaratannya ternyata justru tidak memberikan kepastian kepada pengusaha. Untuk memulai usaha tekstil di Kabupaten Bandung dibutuhkan setidaknya 7 izin dengan berbagai persyaratandan rekomendasi teknis. Hal ini yang sangat menghambat pertumbuhan industri tekstil karena kelembagaan perizinan dipenuhi oleh banyaknya aturan formal yang tidak dilaksanakan secara optimal sehingga justru menimbulkan ketidakpastian.Banyaknya izin yang harus dipenuhi ini pada akhirnya membawa konsekuensi biaya pada perusahaan. Besarnya biaya ini bukan karena tingginya retribusi tetapi lebih disebabkan oleh tingginya biaya pertemanan, dan pungutan pada setiap tahapan proses perizinan. Hal ini juga diungkapkan oleh Brunetti, et al ${ }^{68}$ bahwa hambatan bagi pengusaha untuk menjalankan bisnis diantaranya adalah aturan untuk memulai usaha, aturan perburuhan, dan aturan lingkungan hidup. ${ }^{69}$ Sebagai akibat dari tidak optimalnya pelaksanaan aturan formal maka muncul beberapa aturan informal untuk mengisi kekosongan yang ditinggalkan oleh aturan formal.Pelaksanaan aturan formal ini, terutama dalam hubungan $B$ to $G$ dan $B$ to Society, dirasakan oleh pengusaha sebagai suatu keharusan yang sangat memberatkan karena sangat berpotensi untuk terjadinya pungutan dan praktek suap..$^{70}$

Aturan yang tidak mendorong produktifitas perusahaan.

Hasil penelitian ini juga menunjukkan bahwa ada beberapa aturan formal yang terlalu dipaksakan untuk semua skala perusahaan tekstil. Dan disisi lain juga terdapat aturan yang dianggap pengusaha terlalu "mengada-ada" yang diantaranya adalah retribusi alat penangkal petir dan alat pemadam kebakaran.

Banyaknya pungutan

Praktek pungutan ini meskipun oleh sebagian pengusaha dianggap "masih wajar" tetapi tetap saja memberatkan bagi sebagain besar pengusaha lainnya.

64 North, 1991:97

65 North, 1993: $5-6$

66 Borner, et al, $1992: 13$

66 Borner, et al, $1992: 13$

67 Chang \& Wu, 2013: 6
68 Brunetti, et al, $1997: 20$

68 Brunetti, et al, $1997: 20$
69 Lihat juga dalam dalam Tybout, $2000: 11$

70 Dalam Chang \& Wu, 2013:6 
Karena hal ini menjadi hambatan dalam kelembagaan dan menyebabkan ekonomi biaya tinggi bagi perusahaan.

\section{Masalah Keagenan Dalam Kelembagaan perizinan}

Hubungan principal(s) dan agent dalam wujud informal adalah hubungan yang terjalin antara pengusaha dan pihak ketiga atau calo yang menampilkan perilaku sebagai agent.Salah satu asumsi dalam analisis biaya transaksi adalah bahwa setidaknya beberapa agent memiliki kecenderungan untuk berperilaku oportunis. ${ }^{71}$ Terlepas dari teori regulasi yang menempatkan manajer dari public utility sebagai agent $^{72}$ dalam konteks penelitian ini posisi agent justru diperankan oleh aparat sebagai orang memberikan layanan kepada pengusaha. Ada kecenderungan bahwa aparat birokrasi memanfaatkan keterbatasan informasi yang dimiliki pengusaha sebagai alat untuk mentransaksikan layanan yang diberikan, Hal ini pada akhirnya menjadi biaya keagenan yang dikemas dalam bentuk biaya pertemanan atau biaya pergaulan.Dalam konteks ini biaya pertemanan dan biaya pergaulan tersebut dibayarkan oleh pengusaha dalam upaya mendapatkan layanan yang lebih bernilai dari aparat.

Kembali pada pengertian biaya transaksi sebagai any costs that arise due to the existence of institutions ${ }^{73}$ maka biaya keagenan merupakan salah satu komponen dari biaya transaksi. Hal ini disebabkan karena biaya keagenan yang dibayarkan oleh pengusaha tidak lain adalah dalam rangka mempertahankan eksistensi perusahaan saat ini dan dimasa yang akan datang. Dalam rangka mempertahan eksistensinya perusahaan harus memiliki izin dan berhubungan dengan pemerintah sebagai stakeholder dan regulator. Sebagai regulator pemerintah seharusnya membuat, melaksanakan aturan main dan mengatur permainan sehingga ada kepastian bagi semua pemain dalam industri. Namun tidak semua aparat pemerintah bisa berlaku netral dalam menjalankan tugasnya.Terdapat oknumoknum aparat yang memanfaatkan jabatannya untuk mencari keuntungan ekonomis dengan berperilaku sebagai agent yang opotunis.

Adanya oknum aparat pemerintah yang merangkap sebagai agent pengusaha ini menunjukkan bahwa kelembagaan perizinan bagi industri tekstil belum berjalan dengan baik. Hal disebabkan karena masih banyak ditemukan praktek percaloan dalam hubungan antara pemerintah dan pengusaha yang mengindikasikan rendahnya etika dalam pelayanan publik. Menurut Barry ${ }^{74}$,ethics of public officeadalah salah satu faktor yang berpengaruh pada kapasitas dan tata kelola kelembagaan. Artinya, tidak dijalankannya kode etik dalam pelayanan publik menunjukkan bahwa kapasitas dan tata kelola kelembagaan masih rendah.Fenomena adanya istilah "orang dalam" dan "biaya pertemanan" membuktikan bahwa hubungan keagenan antara pengusaha dan birokrasi sudah mengakar secara kuat dan melembaga.

\footnotetext{
71 Williamson, $1981: 553$

72 Bos, Dieder, $2001: 2$

73 Cheung, $1987: 55-58$

74 Barry, $2007: 2$
}

\section{Model Kelembagaan Perizinan Bagi Industri Tekstil di Kabupaten Bandung}

Berdasarkan uraian-uraian sebelumnya dapat dideskripsikan bahwa model kelembagaan perizinan bagi industri tekstil di Kabupaten Bandung ditandai oleh adanya aturan formal yang pada satu sisi bertujuan untuk mengatur perilaku semua pihak yang terlibat dalam proses perizinan. Namun disisi lain, aturan formalini tidak dilaksanakan secara optimal sehingga justru menjadi hambatan bagi industri dan memunculkan aturan informal dalam bentuk kebisaan-kebiasaan dalam pengurusan perizinan. Pelaksanaan aturan perizinan yang melibatkan pihakpihak selain BPMPP membawa konsekuensi biaya bagi perusahaan karena pihak-pihak yang terlibat dalam proses perizinan ini juga memiliki perilaku yang oportunis. Model kelembagaan perizinan ini dapat dilihat pada gambar 2 di lampiran 2 .

\section{SIMPULAN}

Berdasarkan uraian pada bagian hasil dan pembahasan, dapat disimpulkan bahwa model kelembagaan perizinan yang ada di Kabupaten Bandung belum tertata dengan baik karena masih tingginya ketidak pastian dalam hal proses, biaya dan waktu penyelesaian perizinan. Ketidak pastian ini terkait dengan adanya hambatan-hambatan kelembagaan dan perilaku aparat yang oportunis yang sangat berpotensi untuk terjadinya praktek suap. Hal ini sekaligus juga mengakibatkan semakin tingginya biaya transaksi yang harus ditanggung pengusaha dalam pengurusan perizinan.

Terkait dengan tingginya tingkat ketidak pastian dalam pengurusan perizinan ini maka melalui penelitian ini dihasilkan beberapa rekomendasi praktis, yaitu :

Pemerintah Kabupaten Bandung agar meninjau kembali Peraturan Daerah yang terkait dengan perizinan usaha karena perizinan usaha tersebar pada beberapa peraturan daerah. Akan lebih memudahkan jika beberapa Perda tentang perizinan usaha ini dijadikan dalam satu Peraturan Daerah sehingga lebih memudahkan bagi masyarakat untuk memahaminya.

Pemerintah Kabupaten Bandung agar meninjau kembali beberapa peraturan daerah yang dinilai sangat kontra produktif seperti perda tentang retribusi penangkal petir dan alat pemadam kebakaran.

Untuk menghindari terjadinya praktek suap dan pungutan dalam proses perizinan, sebaiknya pemerintah Kabupaten Bandung menerbitkan sebuah perda tentang pemberlakuan paket retribusi perizinan sesuai dengan waktu penyelesaian perizinannya. Semakin cepat waktu penyelesaian yang diinginkan, semakin besar retribusi yang harus dibayar pengusaha.

\section{DAFTAR PUSTAKA}

Furubotn, E.G. and Richter, R. (2005), Institutions and Economic Theory. The Contribution of the New Institutional Economics, 2nd revised and extended edition, [1st ed. 1997], Ann Arbor, MI: University of Michigan Press. 
Kristiadi, JB. 1994. Administrasi/Manajemen Pembangunan. Jakarta : LAN

North, Douglas C. 1990. Institutions, Institutional Change and Economic Performance.Cambridge : Cambridge University Press

Ollila, Petri. 2009. Principles of Institutional Economics, Helsinki : University of Helsinki

Schmid, A.A. 2004. Conflict and Cooperation - Institutional and Behavioral Economics. Cambrige : Blackwell Publishing

Siagian, Sondang P. 1994. Patologi Birokrasi : Analisis, Identifikasi, dan Terapannya. Jakarta : Ghalia Indonesia.

Waluyo.2007. Manajemen Publik : Konsep, Aplikasi dan Implementasi Dalam Pelaksanaan Otonomi Daerah. Bandung: CV Mandar Maju

Avellaneda , Sebastian Dellepiane, 2006. Good Governance, Institutions and Economic Development: Beyond the Conventional Wisdom. Paper to be presented at the Forum de Recerca, Departament de Ciencies Politiques i Socials, Universitat Pompeu Fabra, Barcelona 3 de Mayo 2006. http://www.upf.edu/dcpis/pdf/sdellepiane. pdf

Barry, Frank. 2007. Structures and Institutions of Good Governance: A View from Ireland Trinity College Dublin. March 2007. http://www.jvi. org/fileadmin/jvi_files/DG_ECFIN_Conference/ Frank Barry Paper on Governance in Ireland and Balkans.pdf

Brunetti, Aymo, Gregory Kisunko and Beatrice Weder.1997.Institutional Obstacles for Doing Business Data Description and Methodology of a Worldwide Private Sector Survey. Work Bank. http://siteresources.worldbank.org/

INTWBIGOVANTCOR/Resources/wps1759.pdf

Borner, Silvio, Aymo Brunetti, \& Beatrice Weder. 1992. Institutional Obstacles to Latin American Growth. San Francisco : An International Center for Economic Growth Publication ICS Press

Bos, Dieter. 2001. Regulation : Theory and Concepts. University of Bonn.

Chang, Sea - Jin \& Brian Wu. 2013. Institutional Barriers and Industry Dynamics. http:// ssrn.com/abstract $=1350531$. Page 6-7 Cheung, Steven N. S. 1987. Economic organization and transaction costs.

The New Palgrave: A Dictionary of Economics v. 2,. pp. 55-58

Commons John R. 1931. Institutional Economics. American EconomicReview, Vol.21, p.648-657, 1931
Ferreiro, Jesus \& Felipe Serrano, 2011.The institutional dimension of new Economic policy, International Journal of Public Policy, Inderscience Enterprises Ltd, vol. 7(1), pages 70-82, January 2011 (http://ideas.repec.org/a/ids/ ijpubp/v7y2011i1p70-82.html diakses 10 Januari 2012)

Jensen, Michael C and William H. Meckling. 1976. Theory of the Firm: Managerial Behavior, Agency Costs and Ownership Structure. Journal of Financial Economics, October, 1976, V. 3, No. 4, pp. 305-360. Reprinted in Michael C. Jensen, $A$ Theory of the Firm: Governance, Residual Claims and Organizational Forms (Harvard University Press, December 2000)

Luo, Yadong \& Marc Junkunc. 2008. How Private Enterprises Respond to Government Bureaucracy in Emerging Economies : The Effects of Entrepreneurial Type and Government. Strategic Entrepreneurship Journal 2 : 133 - 153 (2008). Published online in Wiley InterScience (www.interscience.wiley.com) DOI : 10.1002/ sej.46. http://www.management.pamplin.vt.edu/ directory/Articles/Junkunc2.pdf

North, Douglas C. 1991. Institutions. The Journal of Economic Perspectives, Vol. 5, No. 1. pp. 97-112. published by American Economic Association.

1993.The New Institutional Economics and Development.Washington : Washington University

(http://www.deu.edu.tr/userweb/sedef.akgungor/ Current\%20topics\%20in\%20Turkish\%20 Economy/north.pdf. diakses 8 Juli 2012)

Tybout JR. 2000.Manufacturing Firms in Developing Countries: How Well Do They Do, And Why? Journal of Economic Literature 38(1): 1144.

Verriest, Arnt, Laurens Cherchye, Ann Gaeremynck. 2008. Institutional Characteristics and Firm Profitability. Katholieke Universiteit Leuven July 2008. http://papers.ssrn.com/sol3/papers. cfm?abstract $\mathrm{id}=1013143$

Williamson, Oliver E. 1981. The Economics of Organization : The Transaction Cost Approach. American Journal of Sociology.Volume 87. Issue 3 November 1981 p 548 - 577

Zenger, Todd R, Sergio G Lazzarini \& Laura Poppo. 2002. Informal and Formal Organization in New Institutional Economics, Vol. Iss: 19, pp.277 - 305. Emerald Group publishing Limited. (http://www.emeraldinsight.com/journals. htm? articleid $=1782117 \&$ show $=$ html diakses 25 Juni 2012)

Undang-Undang Republik Indonesia No 28 Tahun 2009 Tentang Pajak dan Retribusi Daerah 
Peraturan Daerah Kabupaten Bandung Nomor 13 Tahun 2012 Tentang Perizinan Tertentu di Kabupaten Bandung.

Peraturan Bupati Kabupaten Bandung Nomor 13
Tahun 2008 Tentang Penyelenggaraan Pelayanan Perizinan Terpadu di Kabupaten Bandung.

BPS Jawa Barat. 2011. Berita Resmi Statistik Jawa BaratNo. 22/05/32/Th. XIII, 5 Mei 2011 